\title{
Post-Apocalypse: Culture and Nature in Gundega Repše's and Cormac McCarthy's Works
}

\author{
INESE VIČAKA
}

\begin{abstract}
The paper focuses on nature and culture in a post-apocalyptic world, which becomes devoid of life and culture and poses a question of further existence of nature in the world. The works of the Latvian writer Gundega Repše and the American writer Cormac McCarthy are analysed in a comparative way to see how nature, set on a bleak stage with the only decoration of empty houses, can give a promise of further existence. Do the two works make it possible to answer the question of existence at its turning point: 'How many people does this world need to be a fully natural and cultural place to inhabit?' The paper tackles this issue from the perspective of ecofeminism and ecocriticism.
\end{abstract}

Keywords: ecocriticism, ecofeminism, post-apocalypse, nature, culture

The recent post-apocalyptic narratives of the American writer Cormac McCarthy and the Latvian writer Gundega Repše attempt to raise our awareness of environmental issues and therefore both serve as an applicable subject for an ecocritical study. One of the motivations for a comparative study of the two contemporary authors was recent work done by Estonian researchers Maris Sõrmus and Julia Tofantšuk who carried out an ecocritical study of seemingly two different novels: Graham Swift's Tomorrow and Andrus Kivirähk's Mees, kes teadis ussisõnu (The Man Who Spoke Snakish). ${ }^{1}$ Their study explored environmental issues topical in the $21^{\text {st }}$ century, which is also the case with current research. Initially, McCarthy's The Road (2006) and Repše's Stigma (2007) could as well appear rather dissimilar, but, taking a closer look at both literary texts one cannot deny that there is more common ground than might be expected. Though in many literary texts nature works as a representative agent of the author's national identity, in McCarthy's narrative The Road (2006) and Repše's Stigma it essentially serves as a mediator, as a provider of understanding of post-apocalyptic drama on a more global scale,

1 See Sõrmus, Tofantšuk 2013.

DOI: http://dx.doi.org/10.12697/IL.2015.20.2.7 
VIČAKA

where the non-human environment speaks of nothing but destruction caused by an unnamed global cataclysm.

The change of the environment imagined in both works expresses a break in the former deep unity of the land, humans and culture, be it rural or urban. Both texts have their own way of dealing with the issues of apocalypse and postapocalypse, which makes it worth inspecting the interplay between the human and nonhuman nature in both texts on the metaphoric and symbolic levels. In what follows, first, a theoretical framework of ecocriticism is provided, and then the analysis of the ecological issues manifest in both literary texts from an ecocritical standpoint is offered.

Ecocriticism was born in the United States when in the late 1970s William Rueckert coined the term (Buell 2009: 13) in his essay "Literature and Ecology" to refer to "the application of ecology and ecological concepts to the study of literature” (Dobie 2011: 238). Rueckert's essay initially did not get enough support from the mainstream literary theorists, only in the nineties with the establishment of the Association for the Study of Literature and Environment (ASLE, 1992) and the publication of the anthology Ecocritcism Reader (1996) produced by Cheryll Glotfelty and Harold Fromm, "ecocriticism was effectively introduced to a broader scholarly audience" (Witschi 2011: 369). More and more critics turned their attention to the study which urged the reader to explore the relationship of literature and nature to renew the reader's awareness of the nonhuman world and his/her responsibility to sustain it. At present literary ecocriticism has grown into a broad and mature field and has become more diversified (Mayers 2006, Buell 2009, Fromm 2009, Witschi 2011). Greg Garrard with his new work, The Oxford Handbook of Ecocriticism (2014), has pronounced ecocriticism to have come of age as a movement, as witnessed by the massive proliferation of anthologies on ecocriticism. Therefore, ecocriticism has already changed the landscape of literary studies, positioning itself in the mainstream. These positive indicators have contributed to the exploration of the issue of ecocriticism in American and Latvian literatures. Besides, as the ecocritic Greg Garrard has postulated in his book Ecocriticism, "apocalypse is the single most powerful master metaphor that the contemporary environmental imagination has at its disposal" (2004: 93), which makes the two chosen environmentally canonical works worth exploring from the perspective of ecocriticism.

Notwithstanding the fact that the Latvian literary oeuvre naturally differs from the American one, the works of the author of the Western canon Cormac McCarthy and Latvian writer Gundega Repše still share similarities, which makes the exploration consistent from the perspective of ecocriticism. Almost simultaneously (in the years 2006 and 2007) both writers decided to 
Post-Apocalypse: Culture and Nature in Gundega Repšse's and Cormac McCarthy's Works

devote their literary careers to producing work on the apocalyptic vision of an environmental catastrophe which turns out to be their first bold step in approaching climate change. Both literary texts explore particular instances of apocalyptic damage, combining ecological, social and individual perspectives on the symbolic and metaphorical levels. Both novels tell about an unspecified catastrophe that has abruptly destroyed the earth's ecosystem and show largely through the lens of the omniscient narrator what would happen if the world should lose its biosphere and the only survivors were just a dozen of humans. Neither author is interested in the immediate circumstances of the apocalyptic events themselves; instead, each text gives the aftermath of the end, which is highly similar: it produces fear, chaos, violence, loss of morality, yet hope for redemption. Environmental rhetoric dominates both works that elegies to lost nature, expressing grief and mourning. Moral depression and the justifiable surrender of humans are seemingly at one with the damage done to the environment. There is no chance of a long-term survival in the world that is devoid of clean nature. Both texts share a confusing combination of the hopeless starkness of the post-apocalyptic reality and divine hope in the continued dialogue with God.

In more detail, McCarthy's novel The Road narrates the journey of a father and son through the post-apocalyptic wasteland of what was the former U.S., while the novel Stigma narrates the travels of nine young people around Europe on the threshold of the apocalypse and later through the post-apocalyptic ruins of the deserted landscape and cities. While McCarthy's novel imagines America's return to wilderness with almost all marks of civilization removed, where "humans become marked as beasts - the frightening animalistic inhabitants of a jungle - as they steal, kill and cannibalize each another" (Estes 2013: 48), Stigma makes an issue of the death of the entire human culture. Naturally, neither writer has consciously taken up the ecocritical sword but both texts feature the issues important in ecocritical studies. There is no doubting the ecocritical value of McCarthy's and Repše's texts when considering "how humans would fare in the face of the total collapse of the biosphere and in the absence of redemptive divine intervention" (Westling 2013: 213).

The vision of apocalypse in both works emerges almost in the first pages with "mist becoming uniform and impenetrable" (Repše 2007: 85, tulk. Inese Vičaka) and "darkness like the onset of some cold glaucoma dimming away the world” (McCarthy 2006: 3). The beginning of both texts brings their readers to an unknown catastrophe that has caused damage to nature and the environment not only at the local but at the global level, the end of the world is in the air. Later the readers are made aware that "even more efficient and deadly technology in combination with radical flaws of human nature will spell doom 
VIČAKA

for the natural world" (Rehill 2009: 55). Nature and culture are intertwined in Repše's work:

Houses, plants, warehouses, military bases, schools and shops - past - past past - high-voltage power lines have helplessly spread their infantile, dry tentacles; thousands of cars on the roadsides, at the gas stations, on the highways and on the flowery, bewitched meadows. Trucks, freezers, buses, cars and motorcycles scattered all around like discharged cartridge cases as far as the horizon goes, then disappear to appear again hours later again scattered in front of one's eyes like stiff, tinted dices (2007: 63, transl. Inese Vičaka).

A similar vision of the damage caused by radical flaws of human nature and the effect of deadly technology is envisioned in McCarthy's text: "The city was mostly burned. No sign of life. Cars in the street caked with ash, everything covered with ash and dust. Fossil tracks in the dried sludge." (McCarthy 2006: 10).

When reading both novels, multitudes of questions have to be scrutinized and considered in the light of Teresa Heffernan's work Post-apocalyptic Culture. Is the post-apocalypse redemptive or traumatic? What does the world that has abandoned 'a sense of an ending' look like? What does it mean to try to "pass beyond the man"? (Heffernan 2008: 23).

This post-apocalyptic fiction, from an ecocritical perspective, "reconfigures the conditions under which humans live and demands that humans rethink their premises for peaceful living together" (Curtis 2010: 5), above all in the light of how nature and the environment are treated. The landscape in Repše's text is seen as bereft of the purity that once was taken for granted:

They drive day and night. Light changes, roads change, turn follows turn, fuel drips and at times women's tears; borders and empty checkpoints; a trivial, unnerving landscape and an azure sky, church towers and cemetery crosses, unemptied recycle bins and pigeon droppings, sliding, empty boats without wind. (2007: 72)

A very similar vision of the landscape can be found in McCarthy's text, where, to speak in ecocritical terms borrowed from Lawrence Buell (2009), the nonhuman environment is present not merely as a framing device but as a presence, where it speaks of total devastation and destruction: 
Post-Apocalypse: Culture and Nature in Gundega Repše's and Cormac McCarthy's Works

The wreckage of buildings strewn over the landscape and skeins of wire from the roadside poles garbled like knitting...The road was littered with debris and it was work to get the cart through. Finally, they just sat by the side of the road and stared at what was before them. Roofs of houses, the trunks of trees, a boat. The open sky beyond. (McCarthy 2006: 231)

The nonhuman environment becomes a meaningful presence which clearly serves as a warning for the readers to take further steps in their care for nature and the surrounding environment as it is the key to life on Earth.

From an ecocritical standpoint, nature in both texts has become transcendental, and at the same time it is, as Timothy Morton in his book Ecology without Nature states, "sandwiched between terms such as God and matter" (Morton 2007: 15). The characters, encapsulated in the harsh environment, curse and at the same time plead for mercy or for an answer from God. The omniscient narrator himself knows the answer to their pleas and, supposedly, readers have also been led to the new awareness of their responsibility for their environment: "Will I see you at the last? Have you a neck by which to throttle you? Have you a heart? Damn you eternally have you a soul?" (McCarthy 2006: 10) Repše brings into her text the same awareness that one may question the presence of God in post-apocalyptic nature: "Oh, High Companion, why should we praise and honour you, when you feast your eyes upon our weeping faces and flesh chasend by fear?" (Repše 2007: 61) From an ecocritical standpoint The Road and Stigma are texts that can be called "without nature" in the sense that is used by Morton in his book. The sun in The Road is obscure, almost unseen against the bleak landscape, bereft of signs of natural life: "Cold and growing colder...The track of the dull sun moving unseen beyond the murk." (McCarthy 2006: 12) Likewise, the sun in Stigma veils itself behind a transparent cobweb; the earth is dying beneath the sun that is wreathed in a cobweb, where the wind gives no sign of tenacity: "The morning is filled with flat, ringing light. The sun is round, like circled with a compass, wreathed around with fine, transparent hairs of the cobweb, which is imperceptibly quivering in the absent wind." (Repše 2007: 58)

Characters in both texts are tested against the harsh environment; the metaphors of nature speak about the harm done to the surroundings, highlighting the relationships between the human and the non-human worlds. This last relationship has been explored by Cheryll Glotfelty, Harold Fromm, Lawrence Buell, Pramod Nayar and Timothy Clark. The agency of nature is present in McCarthy's and Repše's texts, following the stipulation expressed by Lawrence Buell that in environmental literary texts "the nonhuman 
VIČAKA

environment must be envisaged not merely as a framing device but as an active presence" (2009: 25). This allows one to think of The Road and Stigma as inherently ecofiction, and thus suited for ecocritical analysis, bearing in mind Jim Dwyer's stipulation that "most texts can be analysed ecocritically, [but] some are more inherently ecological than others, including many works of contemporary fiction" (Dwyer 2010: 2). Ecofiction is "a composite subgenre made up of many styles, primarily modernism, postmodernism, realism and magic realism, and can be found in many genres" (ibid. 3). Ecofiction is also a component of two related literary phenomena that the ecocritic Patrick Murphy calls "nature-oriented literature" and "environmental literature". This nature-oriented literature "is limited to having either nature itself as the subject, character or major component of the setting, or to a text that says something about human-nonhuman interaction" (Murphy 2000: 4), which very much fits the texts by McCarthy and Repše.

Ecocriticism deals with the phenomena of apocalypse and post-apocalypse. Greg Garrard in his most recent book, The Oxford Handbook of Ecocriticism, has stated that "a crucial factor for ecocriticism is the extent to which the apocalyptic plot is combined with elements of literary realism, giving us characters and events that seem consistent with real possibility" (Garrard 2014: 372). From this ecocritical perspective, it can be well seen that in both texts the apocalyptic and post-apocalyptic scenario is more than real, it is not tentative. Garrard himself does not see the description of the post-apocalypse in McCarthy's The Road as plausible: “[T] he novel's dreadful scenario, in which an unspecified catastrophe has abruptly destroyed the earth's ecosystem, killing plant-life and animal-life but not human-life, does not conform to any scientifically conceivable possibility." (Ibid. 374.) Still, one cannot reject the dreadfulness of the scene, not only in The Road, but also in Stigma, which take the readers to the utmost point of feeling the breath of reality. Matthew Carbery in his essay "Darker Woods Beyond" has supported the idea that McCarthy's text is highly similar to the possible reality of the post-apocalyptic vision. "It is difficult to read The Road without feeling the overwhelming cumulative force of the novel's desolation, and this desolation is most prominently present in the landscape McCarthy portrays." (Carbery 2009: 20) The same feeling of overwhelming desolation is in the landscapes Repše presents. This common vision of the desolate landscape and alienated characters in both narratives makes the reader reassess the relationship of humans and their environment. The environment is indifferent to humanity that is responsible for the damage done to it. Damage for Carbery is man-made, the result of our negligent attitude towards nature. From the perspective of ecocriticism it is a response to our world's contemporary problem which threatens our existence or to put it more 
Post-Apocalypse: Culture and Nature in Gundega Repše's and Cormac McCarthy's Works

ecologically correctly, the world and our place in it. Our negligent attitude is definitely present in Repše's novel.

McCarthy's and Repše's works tackle not only the issue of ecocriticism but also the issue of ecofeminism. Their women - the wife of the father's son in McCarthy's text and Asja in Repše's - are victims of the oppressive and violent culture. In both texts women try to escape from the physical power that can subjugate them to pain and death.

McCarthy and Repše do not end their narratives with a negative vision. On the metaphorical level they both offer a possibility of redemption, a possibility of change that brings a hope, yet distant, that humans have at their disposal a tool that can bring back nature, if not in its original, so-called David Thoreau's state described in Walden, then in a state that does not pose any threat to their further existence. Despite the fact that life on Earth appears to be on its last legs, the unnamed boy in McCarthy's novel lastly finds the so-called good guys who will help: "A soft, unsound fog protrudes its hand. Little John calls out: Footprints! Someone has recently walked with wide, confident steps - around the house, the bathhouse, at the cattle-shed and the threshing barn." (2006: 241) In Stigma Victory's little son, returning home, accidentally finds fresh footprints left by an unknown human, bringing hope that civilization is not totally extinct. McCarthy's and Repše's novels offer a promise of redemption when humans realize that nature has to be saved to prevent extinction on a global scale.

\section{Inese Vičaka \\ advos@inbox.lv \\ Visvalža ielā 4a \\ LV-1050 Rìga \\ LATVIJA}

\section{Bibliography}

Buell, L. 2009. The Future of Environmental Criticism: Environmental Crisis and Literary Imagination. Oxford: Blackwell Publishing.

Carbery, M. 2009. Darker Woods Beyond: An Ecocritical Reading of Cormac McCarthy's Fiction. www.academia.edu (14.11.2015).

Curtis, C. 2010. Postapocalyptic Fiction and the Social Contract: We'll Not Go Home Again. Maryland: Lexington Books.

Dobie, A. 2011. Theory into Practice: An Introduction to Literary Criticism. Boston: Cengage Learning. 
VIČAKA

Dwyer, J. 2010. Where the Wild Books Are: A Field Guide to Ecofiction. Nevada: University of Nevada Press.

Estes, A. 2013. Cormac McCarthy and the Writing of American Spaces. Amsterdam: Rodopi.

Garrard, G. 2014. The Oxford Handbook of Ecocriticism. Oxford: Oxford University Press.

Garrard, G. 2004. Ecocriticism. Oxfordshire: Routledge.

Glotfelty, C., Fromm H. 1996. The Ecocriticism Reader: Landmarks in Literary Ecology. Georgia: University of Georgia Press.

Heffernan,T.2008.Post-apocalyptic Culture: Modernism, Postmodernism, and the Twentieth-Century Novel. Toronto: University of Toronto Press.

McCarthy, C. 2006. The Road. New York: Alfred A. Knoff.

Morton,T. 2007. Ecology without Nature: Rethinking Environmental Aesthetics. Cambridge: Harvard University Press.

Murphy, P. 2000. Farther Afield in the Study of Nature-Oriented Literature. Charlottesville and London: University Press of Virginia.

Rehill, A. 2009. The Apocalypse Is Everywhere. The Apocalypse Is Everywhere: A Popular History of America's Favorite Nightmare.California: ABC-CLIO.

Repše, G. 2007. Stigma. Rīga: Zvaignze ABC.

Sõrmus, M., Tofantšuk, J. 2013. Ecocritical Considerations of Nature in Contemporary British and Estonian Literature. - Interlitteraria, 18/1, 108-123.

Westling, L. 2013. The Cambridge Companion to Literature and the Environment. Cambridge: Cambridge University Press.

Witschi, N. 2011. A Companion to the Literature and Culture of the American West. New Jersey: Wiley-Blackwell. 